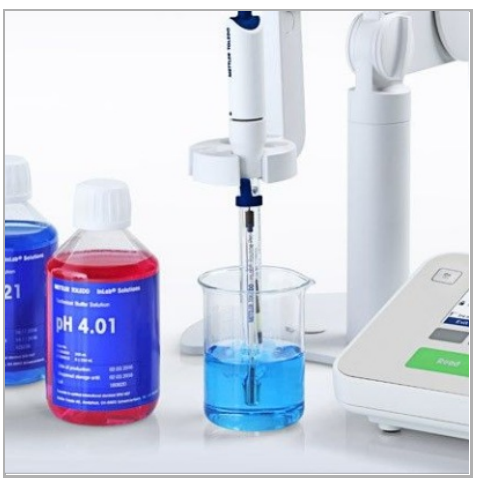

JUN 03, 2020

\section{open Әaccess}

DOI:

dx.doi.org/10.17504/protocol s.io.bfyfjptn

Protocol Citation: Neilier Junior 2020. Citrate Buffer. protocols.io

https://dx.doi.org/10.17504/p rotocols.io.bfyfjptn

License: This is an open access protocol distributed under the terms of the Creative Commons Attribution License, which permits unrestricted use, distribution, and reproduction in any medium, provided the original author and source are credited

Protocol status: Working We use this protocol and it's working

Created: May 05, 2020

Last Modified: Jun 03, 2020

PROTOCOL integer ID:

36583

Keywords: $\mathrm{pH}$, HendersonHasselback, Biochemistry, Molecular Biology

\section{(3) Citrate Buffer}

\section{In 1 collection}

Neilier Junior ${ }^{1}$

${ }^{1}$ Universidade Federal de Viçosa

Neilier Junior

Universidade Federal de Viçosa, University of Manitoba

\section{ABSTRACT}

A buffer solution has the function of resisting changes in $\mathrm{pH}$ even when adding powerful acids or bases. However, in the physiological environment the buffered system also provides cofactors for enzymatic reactions, critical salts and even essential nutrients for cells and tissues. Therefore, when trying to reproduce biological conditions in vitro, we must make the appropriate choice of the buffer. After all, it will provide the appropriate medium in which reactions will occur.

\section{MATERIALS \\ - Deionized Water \\ - pH Meter (sensitive) \\ - Citric Acid \\ - Sodium Citrate Dihydrate}

\section{SAFETY WARNINGS}

(1) Wear personal protective equipment: gloves, lab coat and mask.

\section{BEFORE START INSTRUCTIONS}

Organize your workspace.

Make sure all solutions and equipment are available.

\title{
Citrate Buffer
}


Note

$\mathrm{pH}$ range: (․ㅏ 3.0 to 6.2

(a) $0.1 \mathrm{M}$ Citric acid: $19.21 \mathrm{~g} \mathrm{~L}^{-1}$ (M.W.: $192.1 \mathrm{~g} \mathrm{~mol}^{-1}$ )

(b) $0.1 \mathrm{M}$ Sodium citrate dihydrate: $29.4 \mathrm{~g} / \mathrm{l}$ (M.W.: $294.0 \mathrm{~g} \mathrm{~mol}^{-1}$ )

Mix citric acid and sodium citrate solutions in the proportions indicated and adjust the final volume to I $100 \mathrm{~mL}$ with deionized water.

\begin{tabular}{|l|l|l|l|l|l|l|l|l|l|}
\hline $\mathrm{mL}$ of Citric acid & 46.5 & 40.0 & 35.0 & 31.5 & 25.5 & 20.5 & 16.0 & 11.8 & 7.2 \\
\hline $\mathrm{mL}$ of Sodium citrate & 3.5 & 10 & 15.0 & 18.5 & 24.5 & 29.5 & 34.0 & 38.2 & 42.8 \\
\hline $\mathrm{pH}$ & 3.0 & 3.4 & 3.8 & 4.2 & 4.6 & 5.0 & 5.4 & 5.8 & 6.2 \\
\hline
\end{tabular}

2 Adjust the final $\mathrm{pH}$ using a sensitive $\mathrm{pH}$ meter.

Note

The use of pentahydrate salt of sodium citrate is not recommended. 